\title{
Note
}

\section{Compression Loss Tangent of Micro-Cell Polyurethane Foams in which Bonding Tape Made of Acryl Foam is Sandwiched}

\author{
Hiromasa ADACHI \\ Nagoya Municipal Industrial Research Institute \\ 3-4-41,Rokuban,Atsuta-ku, Nagoya 456-0058, Japan
}

\begin{abstract}
Temperature and frequency characteristics of compression loss tangent of micro-cell polyurethane foams in which bonding tape made by acryl foam was sandwiched, were investigated by dynamic viscoelastic measurements. The larger the thickness of bonding tape or the smaller the storage modulus of the micro cell polyurethane foam, the loss tangent of compound model type sample in normal temperature become to be larger. Therefore, the larger the difference of the storage modulus, the loss tangent of compound model type sample may be larger by the hystereisis of the tension and compression deformation.
\end{abstract}

Key Words: Polyurethane foam / Acryl foam / Dynamic modulus / Viscoelastic measurement / Loss tangent

\section{アクリルフォーム接合テープを挟んだ マイクロセルポリウレタンフォームの圧縮損失正接}

足立 廣正

（原稿受理：2007年12月 5日）

1. 緒言

マイクロセルポリウレタンフォームは従来のポリウレタ ンフォームと異なり，微細で均一なセル構造をもつウレタン フォームであり，小さな圧縮残留ひずみ，優れたシール性， エネルギー吸収性，寸法安定性などにより情報機器，家電・ $\mathrm{AV}$ 機器，スポーツ・メディカル製品，自動車部品などに使わ れている. ${ }^{1)}$ 人々の居住環境の快適性への欲求は騒音，振動の 低減を促し, マイクロセルポリウレタンフォームのような軟 質材の振動減衰能に対する関心は高まっており, 制振材の開 発が多くの企業で行われている. 軟質材の振動減衰能の評価 には動的粘弾性測定が適しており, 高分子材料において振動 減衰能を示寸指標として動的粘弾性パラメータである損失 正接が用いられることが多い.21 長谷 ${ }^{3)}$ は熱可塑性エラスト マー (TPE)の制振性を動的粘弾性挙動から説明してTPEのブ レンド, 短繊維補強による制振性の改善について検討した. 東山(4) はポリマーアロイ型のTPEについて損失正接で評価し た. 岸ら ${ }^{5)}$ はCTBNとエポキシ樹脂とのブレンドについて動的 粘弾性と TEM 観察について検討して拘束型制振鋼板の制振 性について評価した.

振動減衰能以外にも高分子材料の動的粘弾性測定による 評価が多く行われている．著者ら ${ }^{6,7)}$ はマイクロセルポリウレ タンフォームの動的粘弾性測定を行い, 動的圧縮弾性率と力
学特性との関係，動的圧縮弾性率，損失正接による耐熱性に ついて明らかにした。邸ら ${ }^{8,9}$ は高分子材料の高次構造と動的 粘弾性パラメータである動的弾性率，損失正接で疲労破損の 進行する過程を解析することにより耐久性に関する疲労破 壊の評価を行った。伊奈ら ${ }^{10)}$ はエポキシ樹脂注型品において 硬化過渡挙動のシミュレーションの精度検証としてゲル化 点と硬化点を動的粘弾性測定の時間変化により求めた．柏原 ら ${ }^{11)}$ はナイロン6の等温結晶化を動的粘弾性測定の時間変化 により，成瀬ら ${ }^{12}$ はゴム材料の劣化度を動的粘弾性測定の温 度依存性により評価した。市川 ${ }^{13)}$ は接着剤・シール剤におけ る塗布工程の評価に動的粘弾性測定の応力依存性，周波数依 存性を用い，エポキシ樹脂の硬化挙動の観察に動的粘弾性測 定の時間変化を用いた.

現在、マイカや炭酸カルシウムの添加や異なるガラス転 移領域をもつ高分子材料のブレンドによる振動減衰能の評 価は多く行われているが，違う高分子材料を積層した試料 の動的粘弾性測定による振動減衰能の評価は行われていな い. 本研究では，アクリルフォーム構造用接合テープを挟 んだマイクロセルポリウレタンフォームの複合型試料につ いて，振動減衰能の評価パラメータである損失正接を測定 してテープの厚みと損失正接との関係，マイクロセルポリ ウレタンフォームの貯蔵弾性率と損失正接との関係を明ら かにした。 


\section{2. 試料と実験方法}

マイクロセルポリウレタンフォームの製造では，ポリオー ルとイソシアナートとの反応によりポリウレタンを生成さ せると同時に，不活性ガスを混入して高速撹挥でフォームを 強制的に作る.この方法は機械発泡法（気体混入法）と呼ば れ，一般に化学発泡法とよばれる水を使用する方法に比べて 高比重かつ微細気泡のウレタンフォームができる. 4 種類の マイクロセルポリウレタンフォームは(株ロジャースイノ アック製の商品名 “ポロン”で，物性をTable Iに示す．静的 弾性率， $25 \%$ 圧縮応力は侏島津製作所製小型卓上試験機 $\mathrm{EZ}$ Testを使用して, 縦 $13 \mathrm{~mm}$, 横 $13 \mathrm{~mm}$, 厚さ $5 \mathrm{~mm}$ の四角柱の 試料に対して試験速度 $3 \mathrm{~mm} / \mathrm{min}$ で試験片を圧縮し, 荷重-ひ ずみ線図のひずみ $2 \sim 7 \%$ における傾きおよびひずみ $25 \%$ にお ける荷重より求めたものである. 使用した接着テープはFig. 1 に試料の断面を示すが，住友スリーエム（株）製のアクリル フォーム接合テープでアクリルフォーム基材の両側にアク リル系粘着剂をもつものである. 物性をTable II に示す。 な お, Table IIの物性值はメーカーのカタログ值である.

測定した試料はアクリルフォーム接合テープをマイクロ セルポリウレタンフォームの Sample 1 4で挟んだものであ る. 厚みはSample 1 4 が $5 \mathrm{mm,} \mathrm{テープが} 0.25,0.40,0.64$, $1.14 \mathrm{~mm}$ である. 以下において複合型試料と表現する.

粘弹性測定装置（侏レオロジ製DVE-V4）により虚数部と 実数部との位相差の正接である損失正接 $(\tan \delta)$ を求めた. 縦 $13 \mathrm{~mm}$, 横3.42 11.14 mm, 厚さ $13 \mathrm{~mm}$ の四角柱の複合型試料 に対して圧縮用の治具を使用し，下の円盤状治具の上に試料 を置いてから上の円盤状の治具を下げ, 試料に $20 \%$ の静的ひ ずみを与えて, 損失正接を求めた. 以下において圧縮モード と表現する. 測定条件はすべて静的ひずみ $20 \%$, 振動振幅 $30 \mu \mathrm{m}$ ，周波数 $8 \mathrm{~Hz}$, 温度 $26^{\circ} \mathrm{C}$ である.

Table I. Physical properties of samples.

\begin{tabular}{|c|c|c|c|}
\hline $\begin{array}{l}\text { Sample } \\
\text { code }\end{array}$ & $\begin{array}{c}\text { Foam } \\
\text { density } \\
\left(\mathrm{kg} / \mathrm{m}^{3}\right)\end{array}$ & $\begin{array}{c}\text { Compression } \\
\text { Modulus of } \\
\text { elasticity (MPa) }\end{array}$ & $\begin{array}{l}\text { Compression stress } \\
\text { at } 25 \% \text { deformation } \\
\text { (MPa) }\end{array}$ \\
\hline 1 & 200 & 0.19 & 0.26 \\
\hline 2 & 320 & 0.31 & 0.46 \\
\hline 3 & 240 & 0.44 & 0.47 \\
\hline 4 & 240 & 0.51 & 0.77 \\
\hline
\end{tabular}

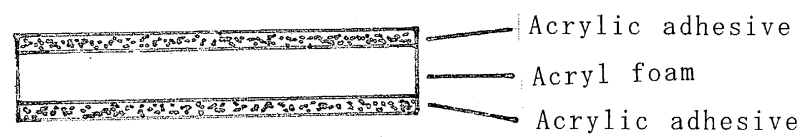

Fig. 1. A section of acrylic tape.

Table II.Physical properties of samples.

\begin{tabular}{ccccc}
\hline $\begin{array}{c}\text { Sample } \\
\text { code }\end{array}$ & $\begin{array}{c}\text { density } \\
\left(\mathrm{kg} / \mathrm{m}^{3}\right)\end{array}$ & $\begin{array}{c}\text { Tensile } \\
\text { strength } \\
(\mathrm{MPa})\end{array}$ & $\begin{array}{c}\text { E1ongation } \\
(\%)\end{array}$ & $\begin{array}{c}25 \% \\
\text { compression } \\
\text { strength } \\
(\mathrm{MPa})\end{array}$ \\
\hline 5 & 750 & 1.2 & 600 & 1.3 \\
\hline
\end{tabular}

\section{3. 結果と考察}

Fig. 2 は複合型試料において Sample 1 4のそれぞれの試料に ついて挟まれたテープの厚みが $0.25,0.40,0.64,1.14 \mathrm{~mm} の$ 場合におけるテープの厚みと複合型試料の損失正接との関 係である. 図中で厚み0は試料1 4のみの場合である. 図中で たとえばSample 1T1 とはSample 1でテープを挟んだ複合型試 料を意味する. また，図中に複合型試料に加わる振動方向を 示してある.すべての複合型試料においてテープの厚みが増 すほど損失正接は大きくなり, Sample 3T3においては試料3の みと複合型試料との損失正接の差は他の複合型試料より大 きい. テープそのままでは厚みが小さすぎて測定できないの で厚み $1.14 \mathrm{~mm}$ のテープを3枚重ねた状態で測定を行ったとこ ろ損失正接は 0.921 であった。これは複合型試料の損失正接 0.230 0.812 と比べて大きく.テープの厚みが増すほど弾性率 の大きいアクリルフォーム接合テープの損失正接に近づく といえる．実用的に自動車分野において多く使われている粘 弾性高分子材料を鋼板の表面に貼り付けた非拘束型制振鋼 板，粘弾性高分子材料を鋼板で挟んだ拘束型制振鋼板におい て，前者は曲げ振動にともなう粘弾性高分子材の伸び変形を 利用しており，後者は曲げ振動にともなう粘弾性高分子材の せん断変形を利用している，樹脂の種類，厚みが同じであれ ば拘束型制振鋼板が非拘束型制振鋼板より制振性能が良い. 粘弾性高分子材にあたるテープの両面にSample 1 4を貼り付 けている当複合型試料の場合は拘束型制振鋼板と同じ三層 であるが，弾性率の大きい鋼板で弾性率の小さい粘弾性高分 子材を挟む拘束型制振鋼板と異なり，弾性率の小さいマイク ロセルポリウレタンフォームで弾性率の大きいアクリル フォーム接合テープを挟んでいる，また，当複合試料におい て変形様式が伸びと縮みを繰り返す伸縮変形である点が非 拘束型制振鋼板に似ている。マイクロセルポリウレタン フォームとアクリルフォーム接合テープの損失正接の值か ら複合型試料の損失正接は複合材における弾性率の複合則 に近い式が推測されるが，厚みの小さいテープの損失正接が 大きく反映されていることから，変形様式である伸縮変形の 違いが複合型試料の損失正接に大きく影響を与えていると

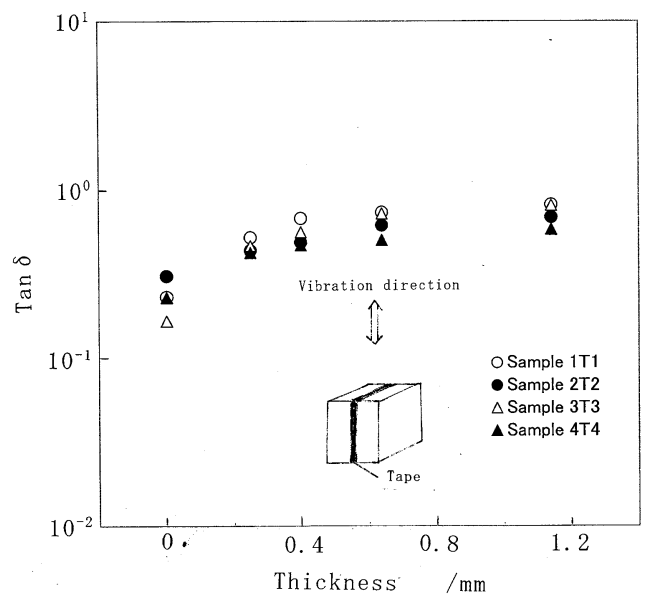

Fig. 2. Dependence of loss tangent on the thickness of acrylic tape. Static strain $20 \%$,vibration amplitude $30 \mu \mathrm{m}$, frequency $8 \mathrm{~Hz}$, temperature $26^{\circ} \mathrm{C}$. 


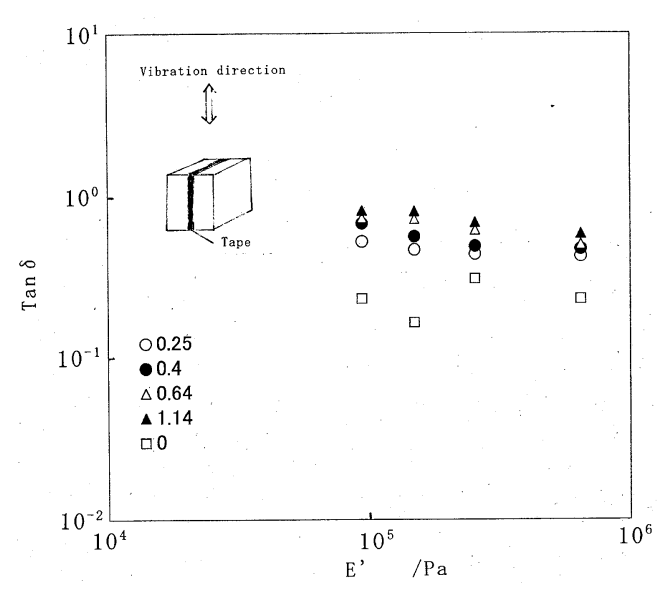

Fig. 3. Dependence of loss tangent on the storage modulus. Static strain $20 \%$,vibration amplitude $30 \mu \mathrm{m}$, frequency $8 \mathrm{~Hz}$, temperature $26^{\circ} \mathrm{C}$.

\section{考えられる.}

Fig. 3はSample 1 4の貯蔵弾性率と複合型試料の損失正接と の関係で，テープの厚みが $0.25,0.40,0.64,1.14 \mathrm{~mm}$ の場合 について比較してある. 厚みが 0 とは試料1 4のみの場合であ る. 複合型試料において貯蔵弾性率が大きくなるほど損失正 接は小さくなる傾向にあるが，厚みが $0.64,1.14 \mathrm{~mm}$ の場合に おいてその傾向が大きい. 試料1 4のみの場合はその傾向は ない. 厚み $1.14 \mathrm{~mm}$ のテープを 3 枚重ねて圧縮モードにより 測定を行ったところ, 貯蔵弾性率は6730kPaであった. Sample 1 4の貯蔵弾性率は順に94，255，1149，645kPaでありテープ に比べてきわめて小さいので, Sample 1 4の貯蔵弾性率が大 きくなるほど複合型試料における Sample 1 4 とテープとの貯 蔵弾性率差は小さくなる。このことは, 非拘束型, 拘束型制 振鋼板の場合において鋼板と粘弾性高分子材との弾性率差 が大きくなるほど伸縮あるいはせん断変形のヒステレシス により制振性能が良くなるのと類似している. マイクロセル ポリウレタンフォームとアクリルフォーム接合テープとの 弾性率差が大きくなるほど, 伸縮振動にともなう伸縮変形の ヒステレシスにより損失正接が大きくなると考えられる．し たがって, 弾性率の大きく異なる材料の複合化により振動減 衰能が向上する可能性がある.

\section{4. 結 論}

マイクロセルポリウレタンフォームにアクリルフォーム 接合テープを挟んだ複合型試料に対して圧縮モードで動的 粘弾性測定を行い，損失正接を求めた。 アクリルフォーム構 造用接合テープの厚いほど，マイクロセルポリウレタン フォームの貯蔵弾性率が小さいほど常温における損失正接 は大きくなることがわかった。これはアクリルフォーム構造 用接合テープとマイクロセルポリウレタンフォームとの弾 性率の違いによる伸縮変形のヒステレシスに起因すると考 えられる。

謝 辞

本研究を進めるに当たり, 試料の提供をしていただいた株 式会社イノアックコーポレーションに謝意を表します。

\section{REFERENCES}

1) Furukawa M and others, "Saishin Polyurethane no Sekkei and Kaishitsu to Kokinoka Gijutsuzenshu”, Gijutsu Zyoho Kyokai (2007).

2) Sumida M, Inoue K, Kogyo Zairyo, 49, 9, 26 (2001).

3) Hase T, Nippon Gomu Kyokaishi, 74, 237 (2001)

4) Higashiyama K, Kogyo Zairyo, 49, 9, 32 (2001).

5) Kishi H, Kobayashi Y, Nagao A, Matsuda S, Asami T, Murakami A, Nihon Setchaku Gakkaishi, 42. 264 (2006).

6) Adachi H, Nihon Reoroji Gakkaishi, 63, 273 (2006).

7) Adachi H, Nihon Reoroji Gakkaishi, 63, 645 (2006).

8) Qiu J, Kawagoe M, Mizuno W, Morita M, Kobunshi Ronbunshu, 56, 255 (2000).

9) Qiu J, Nihon Kikai Gakkai Ronbunshu A, 68, 266 (2002).

10) Ina O, Ishikawa $T$, Sugiura A, Narita R, Nihon Setchaku Gakkaishi, 39, 355 (2003).

11) Kashihara $H$, Takahashi M, Urayama $K$, Takigawa $T$, Zairyo, 54, 55 (2005).

12) Naruse $T$, Hattori $T$, Yamaguchi $Y$, Kanai $T$, Sekiya $T$, Zairyo, 54, 290 (2005).

13) Ichikawa N, Nihon Setchaku Gakkaishi, 41, 281 (2005). 